\title{
The number of spermatozoa in spontaneous ejaculates of rats
}

\author{
A. Ågmo \\ Department of Zoophysiology, University of Uppsala, Box 560, S-751 22 Uppsala, Sweden
}

Spontaneous seminal discharges are known to occur in many mammals, including rats (Orbach, 1961 ; Kihlström, 1966), hamsters (Beach \& Eaton, 1969) and guinea-pigs (Martan, 1968). After such ejaculations the semen rapidly coagulates and if the animals are prevented from grooming the genital area it is possible to collect all the ejaculates delivered. It is known that there is a diurnal variation in spontaneous seminal discharge (Kihlström, 1966), and that there is a sharp decline in frequency of seminal emission following sexual activity in the rat (van Dis \& Larsson, 1970; Beach, 1975). The presence of spermatozoa in spontaneous ejaculates has been confirmed by Orbach (1961) but there are no observations as to the number of spermatozoa in the spontaneous ejaculates, probably because of the difficulty of counting spermatozoa in the coagulated ejacula. Using a modification of the method of Freund (1958) for dissolving coagulated rat semen I have counted spermatozoa in the spontaneous ejaculates from Sprague-Dawley and Wistar rats.

Ten sexually inexperienced Sprague-Dawley rats, 4 months old and weighing $400-420 \mathrm{~g}$, were bought from Anticimex, Sollentuna, Sweden. They were housed singly in cages with wire-mesh floors and given food and water ad libitum. Two weeks after arrival in the laboratory the rats were twice fitted with collars for $24 \mathrm{hr}, 48 \mathrm{hr}$ apart, to accustom the animals to handling. The collars were made of cotton fabric to which was fastened an $8 \mathrm{~cm}$ long whalebone. The stiffness of the whalebone prevented the rats from reaching the genital region with the head but did not disturb their normal movements. During the next 2 weeks the animals were again fitted with the collars for $24 \mathrm{hr}$ once a week. During these periods, spontaneous ejaculates were collected on aluminium foil situated $5 \mathrm{~cm}$ below the cage floor.

Ten Wistar rats, bred at the Laboratoire de Psychophysiologie, Université Paris VI, were treated in the same way as the Sprague-Dawley rats, except that they kept the collars on for $48 \mathrm{hr}$ on every occasion. However, for the purpose of the present study, ejaculates were collected only during the first $24 \mathrm{hr}$. This part of the experiment was performed in Paris at the same time of the year as the other part (early autumn), but 1 year later.

The spontaneous ejaculates were left at room temperature for 1 week to dry. They were then weighed and dissolved in $0.5 \mathrm{ml}$ physiological saline to which had been added $0.02 \%$ sodium azide, $0.115 \mathrm{M}-\mathrm{CaCl}_{2}$ and $0.2 \% \alpha$-chymotrypsin. The $\alpha$-chymotrypsin was added to the solution immediately before use. The tubes containing the seminal plugs and the dissolving solution were left at $37^{\circ} \mathrm{C}$ for $24 \mathrm{hr}$, and were gently shaken two or three times during this period. After $24 \mathrm{hr}$ most of the plugs had dissolved; any that had not done so were left for a further $24 \mathrm{hr}$ at $37^{\circ} \mathrm{C}$ after addition of another $0.5 \mathrm{ml}$ of the dissolving solution. About $95 \%$ of the plugs had completely dissolved by this time and the rest were discarded. It was now possible to count the spermatozoa dissolved from the ejacula in a haemocytometer. The number of spermatozoa in a single plug remained constant if the dissolved plug was left at $37^{\circ} \mathrm{C}$ or at room temperature for another $24 \mathrm{hr}$, indicating that the enzyme did not destroy the spermatozoa. However, the acrosome was almost invariably ( $>99 \%$ ) separated from the rest of the spermatozoon, but this was found to be very useful, since the accuracy of counting was increased by counting only the acrosomes. This was due to the fact that the acrosomes rapidly sedimented to the bottom of the haemocytometer.

As is evident from Table 1 a large majority of rats deposited at least one seminal plug per $24 \mathrm{hr}$, and the mean frequency was 1.93. The Sprague-Dawley rats ejaculated a significantly larger number of spermatozoa both per $24 \mathrm{hr}$ and per plug than did the Wistar rats, although theweights of the seminal plugs were similar in the two strains. However, on the second occasion when semen was collected, the 
Table 1. Characteristics of rat spontaneous ejaculates emitted during two periods of 24 hr each (mean \pm S.E.M.)

\begin{tabular}{|c|c|c|c|c|c|c|c|}
\hline $\begin{array}{c}\text { Strain and } \\
\text { period }\end{array}$ & $\begin{array}{l}\% \text { of rats } \\
\text { producing } \\
\text { plugs }\end{array}$ & $\begin{array}{l}\text { No. of } \\
\text { plugs }\end{array}$ & $\begin{array}{l}\text { Wt of } \\
\text { plugs/rat } \\
(\mathrm{mg})\end{array}$ & $\begin{array}{c}\text { Wt of } \\
\text { plug (mg) }\end{array}$ & 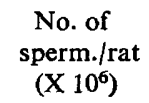 & $\begin{array}{c}\text { No. of } \\
\text { sperm./plug } \\
\left(X 10^{6}\right)\end{array}$ & $\begin{array}{l}\text { No. of } \\
\text { sperm./mg } \\
\left(\times 10^{6}\right)\end{array}$ \\
\hline \multicolumn{8}{|c|}{ Sprague-Dawley } \\
\hline 1 & 90 & 19 & $38 \cdot 6 \pm 7 \cdot 7$ & $19 \cdot 4 \pm 2.2$ & $9 \cdot 5 \pm 2 \cdot 0^{a}$ & $5.0 \pm 0.7^{\mathrm{e}}$ & $0.28 \pm 0.04$ \\
\hline 2 & 80 & 20 & $47.4 \pm 8 \cdot 1$ & $16 \cdot 7 \pm 2.0$ & $15 \cdot 7 \pm 2 \cdot 0^{b}$ & $6.3 \pm 0.8^{t}$ & $0.52 \pm 0.11^{9}$ \\
\hline \multicolumn{8}{|l|}{ Wistar } \\
\hline 1 & 90 & 14 & $25 \cdot 3 \pm 3 \cdot 2$ & $16 \cdot 3 \pm 2 \cdot 1$ & $3 \cdot 1 \pm 0.6^{\mathrm{c}}$ & $2 \cdot 0 \pm 0.4^{e}$ & $0.18 \pm 0.05$ \\
\hline 2 & 100 & 24 & $58.9 \pm 9.0$ & $20 \cdot 8 \pm 2.7$ & $7 \cdot 5 \pm 1 \cdot 4^{d}$ & $2.9 \pm 0.5^{f}$ & $0.18 \pm 0.04^{2}$ \\
\hline
\end{tabular}

a Significantly different from $\mathrm{b}$ and $\mathrm{c}(P<0.05, t$ test $)$; $^{\mathrm{b}}$ significantly different from $\mathrm{d}(P<0.05, t$ test $)$; $^{\mathrm{c}}$ significantly different from $\mathrm{d}(P<0.05, t$ test $){ }^{e, t, z}$, values with the same superscript significantly different from each other $(P<0.05, t$ test $)$.

number of spermatozoa/mg semen was larger in the Sprague-Dawley rats. Comparison of the two periods of semen collection showed that the number of spermatozoa/rat was significantly increased in both strains.

In Table 2, the material has been subdivided according to the number of seminal plugs each rat produced during $24 \mathrm{hr}$. The weight and sperm content of each plug seem to be independent of the number of plugs produced and therefore the larger the number of plugs formed, the larger the total weight and total number of spermatozoa ejaculated. Application of an F-test showed that there was a significant difference in these measures in rats emitting one, two or three seminal plugs.

Table 2. Characteristics of rat spontaneous ejaculates according to the number of ejaculates emitted during $24 \mathrm{hr}$ (mean \pm S.E.M.)

\begin{tabular}{|c|c|c|c|c|c|c|}
\hline Strain & $\begin{array}{l}\text { No. of } \\
\text { plugs }\end{array}$ & $\begin{array}{l}\text { No. of } \\
\text { rats }\end{array}$ & $\begin{array}{l}\text { Wt of plugs/ } \\
\text { rat (mg) }\end{array}$ & $\begin{array}{l}\text { Wt of plug } \\
\text { (mg) }\end{array}$ & $\begin{array}{l}\text { No. of sperm./ } \\
\text { rat }\left(\times 10^{6}\right)\end{array}$ & $\begin{array}{c}\text { No. of sperm./ } \\
\text { plug }\left(\times 10^{6}\right)\end{array}$ \\
\hline \multicolumn{7}{|c|}{ Sprague-Dawley } \\
\hline & 1 & 3 & $7 \cdot 9 \pm 4.9^{a}$ & $17.9 \pm 4.9$ & $6.6 \pm 1.9^{a}$ & $6.6 \pm 1.9$ \\
\hline & 2 & 8 & $37 \cdot 7 \pm 4 \cdot 3^{\mathrm{a}, \mathrm{b}}$ & $18 \cdot 8 \pm 2 \cdot 3$ & $9 \cdot 7 \pm 1 \cdot 2^{b}$ & $4.9 \pm 0.8$ \\
\hline & 3 & 5 & $49 \cdot 9 \pm 3 \cdot 6^{\mathrm{a}, \mathrm{b}}$ & $16 \cdot 6 \pm 2 \cdot 7$ & $18 \cdot 1 \pm 2 \cdot 7^{\mathrm{a}, \mathrm{b}}$ & $6.0 \pm 0.9$ \\
\hline & 4 & 1 & $83 \cdot 4$ & $20.9 \pm 4.8$ & $23 \cdot 0$ & $5 \cdot 7 \pm 1 \cdot 6$ \\
\hline \multicolumn{7}{|l|}{ Wistar } \\
\hline & 1 & 7 & $27.9 \pm 5.8^{a}$ & $27 \cdot 9 \pm 5 \cdot 8$ & $2 \cdot 2 \pm 0.6^{a}$ & $2 \cdot 2 \pm 0.6$ \\
\hline & 2 & 7 & $40 \cdot 4 \pm 7 \cdot 5^{2}$ & $21 \cdot 4 \pm 4 \cdot 1$ & $4 \cdot 7 \pm 0.6^{a}$ & $2.4 \pm 0.4$ \\
\hline & 3 & 2 & $70 \cdot 7$ & $23 \cdot 6 \pm 5 \cdot 2$ & $12 \cdot 6$ & $4 \cdot 2 \pm 0.8$ \\
\hline & 4 & 2 & $81 \cdot 2$ & $20 \cdot 3 \pm 5 \cdot 6$ & $10 \cdot 5$ & $2 \cdot 6 \pm 1 \cdot 2$ \\
\hline
\end{tabular}

Values with the same superscripts significantly different from each other $(P<0.05, t$ test $)$.

I have no explanation for the difference between the two rat strains used, but the general conclusions reached are supported by the results for each strain.

The number of spermatozoa ejaculated at normal copulation has, in the male rat, been estimated as $83 \times 10^{6}$ (Farris, 1946) or $58 \times 10^{6}$ (Blandau \& Odor, 1949). Electroejaculation results in ejaculates containing $63 \times 10^{6}$ (Scott \& Dziuk, 1959) or 55-60 $\times 10^{6}$ (Mauss et al., 1970). It can therefore be concluded that a normal ejaculate as well as an ejaculate obtained by electroejaculation contains at least 10 times more spermatozoa than an ejaculate produced spontaneously. If rats are allowed to mate from 1 to 5 times with a female, then the weights of the spontaneous ejaculates are reduced for 4-9 days afterwards (van Dis \& Larsson, 1970; Beach, 1975). On the other hand, a rat may continue to produce several spontaneous ejaculates every day for weeks without any noticeable decrease in ejaculate weight (A. Ågmo, unpublished observations). 
The characteristics of the individual seminal plugs do not seem to be affected by the frequency of spontaneous ejaculation, which may, at least partly, be determined by the activity of the testes and accessory sex glands. Indeed, Beach (1975) found a significant positive correlation between the weight of the seminal vesicles and frequency of spontaneous ejaculation.

The process of spermatogenesis and formation of secretions in the accessory sexual glands is generally believed to be continuous and, in many species, depends little on the degree of sexual activity. When the animal is prevented from being sexually active, the stores of spermatozoa and accessory gland secretions sooner or later become filled up. It is suggested that, in this situation, the animal ejaculates spontaneously. The well established fact that spermatozoa are found in the urine (Lino, Braden \& Turnbull, 1967) does not exclude the possibility that spontaneous ejaculation may represent an important way of removing spermatozoa.

Financial support was received from the Magn. Bergvall Foundation. Chymotrypsin was generously supplied by Les Laboratoires Choay, France.

\section{References}

BEACH, F.A. (1975) Variables affecting spontaneous seminal emission in rats. Physiol. Behav. 15, 91-95.

Beach, F.A. \& Eaton, G. (1969) Androgenic control of spontaneous seminal emission in hamsters. Physiol. Behav. 4, 155-156.

BLANDAU, R.J. \& OdOR, D.L. (1949) The total number of spermatozoa reaching various segments of the reproductive tract in the female albino rat at intervals after insemination. Anat. Rec. 103, 93-109.

vaN Dis, H. \& LARsSON, K. (1970) Spontaneous seminal discharge and preceding sexual activity. Physiol. Behav. 5, 1161-1163.

FARRIS, E.J. (1946) Spermatozoa counts in albino rats. Anat. Rec. 94, 360-361.

FREUND, M. (1958) Collection and liquefaction of guinea pig semen. Proc. Soc. exp. Biol. Med. 98, $538-540$.

KıнLström, J.E. (1966) Diurnal variations in the spon- taneous ejaculations of the male albino rat. Nature, Lond. 209, 513-514.

Lino, B.F., Braden, A.W.H. \& TuRnBull, K.E. (1967)

Fate of unejaculated spermatozoa. Nature, Lond. 213, 594-595.

MARTAN, J. (1968) Factors affecting spontaneous ejaculation of male guinea pigs. J. Reprod. Fert. 17, 161-163.

Mauss, J., Rausch-Stroomann, J.G., hahn, E., Petry, R. \& Zambal, Z. (1970) Gewinnung, histologische Untersuchungen und Losungsversuche des Ejakulatspfropfes der Ratte. Andrologie 2, 13-18.

Orbach, J. (1961) Spontaneous ejaculation in rat. Science, N.Y. 134, 1072-1073.

ScotT, J.W. \& DzIUK, P.J. (1959) Evaluation of the electroejaculation technique and the spermatozoa thus obtained from rats, mice and guinea pigs. Anat. Rec. 133, 655-664. 